\title{
References
}

\author{
Archives
}

Archives du féminisme, Anger

Fond Képès

Bibliothèque interuniversitaire de Santé, Paris

Fonds Dalsace-Dellay

Butler Library, University of Columbia, New York

Margaret Sanger papers

Manchester Medical Collection, Manchester

Biographical files

University of Victoria, British Columbia

Douglas Goldring papers

Wellcome Library, London

$\mathrm{GC} / 105$ In the club, interview

PP/HRW Helena Rosa Wright Collection

$\mathrm{PP} / \mathrm{MAL}$ Joan Malleson

SA/EUG Eugenics Society Collection

SA/FPA Family Planning Association Collection

SA/MWF Medical Women's Federation Collection

Women's Library, London School of Economics, London

\section{Medical journals}

British Medical Journal

Family Planning 
Gynécologie pratique

Journal of Hygiene

Lancet

Medical Women's Federation Newsletter

Post-Graduate Medical Journal

The Eugenics Review

The Medical Press

The Practitioner

\section{Handbooks}

Charles, E., The Practice of Birth Control: An Analysis of the Birth-Control Experiences of Nine Hundred Women (London: Williams \& Norgate, 1932).

Cox, G., Clinical Contraception (London: Heinemann, 1933).

Cox, G. M., Clinical Contraception, 2nd edition (London: ButterworthHeinemann, 1937).

Dawkins, S., Planning Your Family (London: Foyles Health Handbooks, 1959).

Fielding, M. (ed.), Birth Control in Asia: A Report of a Conference Held at the London School of Hygiene \& Tropical Medicine, November 24-25, 1933 (London: Birth Control International Information Centre, 1935).

Friedman, L. J., Virgin Wives: A Study of Unconsummated Marriages (London: Tavistock Publications, 1962).

Hart, D. B., and A. H. Freeland Barbour, Manual of Gynaecology (Edinburgh: W. \& A. K. Johnston, 1890).

Haire, N. (ed.), World League for Sexual Reform: Proceedings of the Third Congress, London, 1929 (London: Paul, Trench, Trübner, 1930).

Haire, N., Birth Control Methods (Contraception, Abortion, Sterilisation) (London: George Allen \& Unwin, 1936).

Lagroua Weill-Hallé, M.-A., La prescription contraceptive (Paris: Librairie Maloine, 1968).

Macaulay, M., The Art of Marriage (London: Delisle, 1952).

Malleson, J., The Principles of Contraception: A Handbook for General Practitioners (London: V. Gollancz Limited, 1935).

Malleson, J., Any Wife or Any Husband: A Book for Couples Who Have Met Sexual Difficulties and for Doctors (London: Penguin Handbook, 1950).

Moore White, M., Womanhood (London: Cassell, 1947).

Pierpoint, R., Report of the Fifth International Neo-Malthusian and Birth Control Conference: Kingsway Hall, London, July 11 th to 14th, 1922 (London: William Heinemann Medical Books, 1922).

Pollock, M. (ed.), Family Planning: A Handbook for the Doctor (London: Tindall \& Cassell, 1966). 
Sanger, M. (ed.), Medical and Eugenic Aspects of Birth Control: The Sixth International Neo-Malthusian and Birth Control Conference, Volume III (New York: American Birth Control League, 1926).

Sanger, M. and H. Stone (eds), The Practice of Contraception: An International Symposium and Survey (Baltimore: Williams \& Wilkins, 1931).

Secor Florence, L., Birth Control on Trial (London: George Allen and Unwin Ltd., 1932).

Tunnadine, P., Contraception and Sexual Life: A Therapeutic Approach (London: Tavistock Publications, 1970).

Tunnadine, P. and J. Pasmore, 'Sexual problems in marriage in women' in M. Pollock (ed.), Family Planning (London: Tindall \& Cassell, 1966).

Wright, H., The Sex Factor in Marriage: A Book for Those who Are, or are About to Be, Married (London: Noel Douglas, 1930).

Wright, H., Birth Control: Advice on Family Spacing and Healthy Sex Life (London: Cassell, 1935).

Wright, H., More about the Sex Factor in Marriage (London: Williams and Norgate, 1947).

Wright, H., Contraceptive Technique: A Handbook of Practical Instruction, 3rd edition (London: Churchill, 1968).

Wright, H. and H. B. Wright, Contraceptive Technique: A Handbook for Medical Practitioners and Senior Students (London: J\&A Churchill Ltd., 1951).

\section{Articles}

Alabaster, G. H., 'Contraception and fertility', Lancet, 231:5973 (1938), p. 462. Anchel-Bach, M., 'La mortalité maternelle et l'avortement', Bulletin de l'Association français des femmes médecins, 18 (1937), p. 29.

Baker, J. R., 'The spermicidal powers of chemical contraceptives: II. Pure substances', Journal of Hygiene, 31:2 (1931), p. 211.

Balint, M., 'Training general practitioners in psychotherapy', British Medical Journal, 1:4854 (1954), pp. 115-20.

Balint, M., 'Psychotherapy and the general practitioner: I', British Medical Journal, 1:5011 (1957), p. 157.

Balint, M., 'The marital problem clinic - a problem child of the FPA', Family Planning, 9:1 (1960), pp. 18-20.

Barnes, J., 'Sylvia Dawkins', British Medical Journal, 312:7041 (1996), p. 1295.

Barton, M. and B. P. Wiesner, 'The receptivity of cervical mucus to spermatozoea', British Medical Journal, 2:4477 (1946), pp. 606-10.

Blacker, C. P., 'Foreword', International Medical Group for the Investigation of Contraception, 4th issue (1931), p. 3. 
Blacker, C. P., 'The choice of a contraceptive', The Practitioner, 131:3 (1933), p. 256.

Blanchier, D., 'Compte-rendu de l'enquête faite à propos du 'Birth control'!', Bulletin de l'Association française des femmes médecins, 15 (1933), p. 24.

Campbell, J., 'Abortion in relation to maternal mortality', Journal of the Medical Women's Federation, (May 1936), p. 27.

'Contraception', The Practitioner, 111 (1923), p. 5.

E. H., 'Margaret Moore White, Womanhood', Medical Women's Federation Quarterly Review (1959), p. 37.

Eckstein, P. et al., 'The Birmingham Oral Contraceptive Trial', British Medical Journal, 2:5261 (1961), pp. 1172-9.

'Evaluating the I.U.D', Lancet, 1:7854 (1974), pp. 394-5.

Fawcitt, R., 'Revocable sterilisation of the female', British Medical Journal, $1: 3600$ (1930), p. 45.

Gräfenberg, E., 'The intra uterine method of contraception' in N. Haire (ed.), World League for Sexual Reform: Proceedings of the Third Congress, London, 1929 (London: Paul, Trench, Trübner, 1930), p. 611.

Green-Armytage, C., 'Contraceptive', British Medical Journal, 1:3704 (1932), pp. 13-14.

Guttmacher, A. (ed.), Intra-Uterine Contraceptive Devices: Proceedings of the Conference, April 30-May 1, 1962, New York City (New York: Excerpta Medica Foundation, 1962).

Guttmacher, A., 'Intra-uterine contraceptive device', Family Planning, 13:14 (1965), pp. 91-5.

Haire, N., 'Health aspects of birth control' in M. Sanger (ed.), Medical and Eugenic Aspects of Birth Control: The Sixth International Neo-Malthusian and Birth Control Conference, Volume III (New York: American Birth Control League, 1926), p. 95.

Haire, N., 'Revocable sterilisation of the female', British Medical Journal, 2:3597 (1929), p. 1134.

Haire, N., 'Revocable sterilisation of the female', British Medical Journal, 1:3602 (1930), pp. 129-30.

Haire, N., 'Clinical experience of the past year', International Medical Group for the Investigation of Contraception, 4th issue (1931), p. 68.

Haire, N., 'The Gräfenberg ring', British Medical Journal, 1:3705 (1932), pp. 76-7.

Harding, K., 'Sterility in the female', The Medical Press (29 April 1953).

Harding, K., 'Management of infertility', The Medical Press (November 1960), p. 436.

Hick, R. H. P., 'Advice on sterility', British Medical Journal, 1:4300 (1943), p. 707. 
Horder, L., 'Sterility', Lancet, 241:6247 (1943), p. 664.

Houghton, V., 'Report of meeting of International Committee on Planned Parenthood', The Eugenics Review, 43:3 (1951), p. 141.

Huxley, F., 'The clinical study of fertility cases with notes and treatments', Medical Women's Federation Journal (1 July 1935), pp. 28-37.

'Intrauterine contraceptive devices', British Medical Journal, 2:5456 (1965), p. 249.

'Intra-uterine contraceptive device', Family Planning, 15:1 (1966), p. 26.

Jackson, M., 'Birth control and the medical profession', British Medical Journal, 1:3621 (1930), p. 1022-3.

Jackson, M. C. N., 'Contraceptives and fertility', British Medical Journal, 1:4026 (1938), p. 539.

Jackson, M., 'Advice on sterility', British Medical Journal, 1:4303 (1943), p. 803. Jackson, M., 'The organisation of a sterility service within a Family Planning Association clinic', Post-Graduate Medical Journal, 20:225 (1944), p. 237.

Jackson, M., 'A medical service for the treatment of involuntary infertility', The Eugenics Review, 36:4 (1945), p. 117.

Jackson, M., 'Artificial insemination', British Medical Journal, 1:4512 (1947), p. 945.

Jackson, M., 'Human artificial insemination', Family Planning, 9:3 (1960), p. 6.

Jackson, M., 'The Gräfenberg silver ring in a series of patients who had failed with other methods', in A. Guttmacher (ed.), Intra-Uterine Contraceptive Devices: Proceedings of the Conference, April 30-May 1, 1962, New York City (New York: Excerpta Medica Foundation, 1962), pp. 37-40.

Jackson, M., 'Oral contraception in practice', Journal of Reproduction and Fertility, 6:1 (1963), pp. 153-73.

Jackson, M., 'Silver ring and plastic loops, a comparison of intrauterine devices for problem cases', Family Planning, 12:1 (1963), p. 12.

Jackson, M., 'England: family planning in England and India', The Journal of Sex Research, 3:4 (1967), p. 270.

Jex-Blake, S. (1874), 'The medical education of women', a paper read at the Social Science Congress, Norwich, October 1873 (London), p. 3, quoted in L. Kelly, " The turning point in the whole struggle": the admission of women to the King and Queen's College of Physicians in Ireland', Women's History Review, 22:1 (2013), pp. 97-125.

Lewis-Faning, E., 'Report of an enquiry into family limitation and its influence on human fertility during the past fifty years' in The Royal Commission on Population, Papers Vol. 1 (London: HM Stationery Office, 1949).

Malleson, J., 'Contraceptives and fertility', British Medical Journal, 1:4025 (1938), p. 484. 
Malleson, J., 'Vaginismus: its management and psychogenesis', British Medical Journal, 2:4259 (1942), pp. 213-16.

Malleson, J., 'Contraception and sterility', British Medical Journal, 2:4317 (1943), p. 434.

Malleson, J., 'Contraception and sterility', British Medical Journal, 2:4322 (1943), p. 587.

Malleson, J., 'Contraception and sterility', British Medical Journal, 2:4328 (1943), pp. 796-7.

Malleson, J., 'Sexual disorders in women, their medical significance', British Medical Journal, 2:4746 (1951), p. 1480.

McIlroy, A. L., 'The harmful effects of artificial contraceptive methods', The Practitioner (July 1923), pp. 25-35.

Mears, E., 'Clinical trials of oral contraceptives', British Medical Journal, 2:5261 (1961), pp. 1179-83.

Mears, E., 'Oral contraception: the results', Family Planning, 10:4 (1962), p. 4.

'Medical problems of contraception', British Medical Journal, 1:3726 (1932), pp. 1047-8.

'Medical problems of contraception', British Medical Journal, 2:3784 (1933), pp. 118-20.

Montreuil-Strauss, G., 'Le Birth control: exposé historique par MontreuilStrauss', Bulletin de l'Association française des femmes médecins, 12 (1933), pp. 3-22.

Moore White, M., 'The endocrine treatment of sterility', Post-Graduate Medical Journal, 20:225 (1944), pp. 215-22.

Moore White, M., 'The problem of sterility, its investigation and treatment', The Practitioner, 158:946 (1947), p. 279.

Moore White, M. and M. Barton, 'Conception in spite of extreme oligozoospermia', British Medical Journal, 1:4709 (1951), p. 741.

Murphy, K., 'Joan Malleson, the principles of contraception', Medical Women's Federation Quarterly Review (1935-6), p. 65.

Nixon, W. C. W., 'Joan Malleson', British Medical Journal, 1:4978 (1956), p. 1304.

'Obituary', British Medical Journal, 1:4977 (1956), p. 1242.

'Obituary', Lancet, 267:6926 (1956), p. 810.

Pyke, M. A., 'Contraception and fertility', Lancet, 231:5972 (1938), p. 405.

'Reports of societies', British Medical Journal, 2:3157 (1921), p. 11.

Rolleston, H., 'Birth Control Investigation Committee', British Medical Journal, 2:3486 (1927), p. 805.

Valabrègue, C., '48 heures à Londres', La Maternité Heureuse, Bulletin trimestriel d'information, 9 (1959), p. 11. 
Wright, H., 'Revocable sterilisation of the female', British Medical Journal, 1:3602 (1930), pp. 129-30.

Wright, H., 'Notes on the 38 cases fitted with Gräfenberg ring', International Medical Group for the Investigation of Contraception, 4th issue (1931), p. 65.

\section{Secondary literature}

Accampo, E., Blessed Motherhood, Bitter Fruit: Nelly Roussel and the Politics of Female Pain in Third Republic France (Baltimore: Johns Hopkins University Press, 2006).

Akira, I. and P. I. Saunier (eds), The Palgrave Dictionary of Transnational History (Basingstoke: Palgrave Macmillan, 2009).

Al-Gailani, S., "The mothers of England object": public health, privacy and professional ethics in the early twentieth-century debate over the notification of pregnancy', Social History of Medicine, 33:1 (2020), pp. 18-40.

Allen, A. T., 'Feminism and eugenics in Germany and Britain, 1900-40: a comparative perspective', German Studies Review, $23: 3$ (2000), pp. 477-505.

Allen, A. T., Feminism and Motherhood in Western Europe, 1890-1970: The Maternal Dilemma (New York: Palgrave Macmillan, 2005).

Andrew, H., "The Reluctant Stork": Science, Fertility and the Family in Britain, 1943-60'. PhD dissertation, York University Toronto, 2016.

Austoker, J. and L. Bryder, Historical Perspectives on the Role of the MRC (Oxford: Oxford University Press, 1989).

Bajos, N. and M. Bozon (eds), 'La sexualité à l'épreuve de la médicalisation: le cas du Viagra', Actes de la Recherche en Sciences Sociales, 128 (1999), pp. 34-7.

Bard, C., Les filles de Marianne: Histoire des féminismes; 1914-40 (Paris: Fayard, 1995).

Bard, C. and J. Mossuz-Lavau, Le planning familial: histoire et mémoire, 1956-2006 (Rennes: Presses Universitaires de Rennes, 2007).

Bashford, A., Purity and Pollution: Gender, Embodiment and Victorian Medicine (Basingstoke: Macmillan Press Ltd., 1998).

Bashford, A., 'Nation, empire, globe: the spaces of population debate in the interwar years', Comparative Studies in Society and History, 49:1 (2007), pp. 170-201.

Bashford, A., Global Population: History, Geopolitics, and Life on Earth (New York: Columbia University Press, 2014).

Bashford, A. and P. Levine (eds), The Oxford Handbook of the History of Eugenics (Oxford: Oxford University Press, 2010).

Beachy, R., 'The German invention of homosexuality', The Journal of Modern History, 82:4 (2010), pp. 801-38. 
Beauchamp, T. L., 'Informed consent: its history, meaning, and present challenges', Cambridge Quarterly of Healthcare Ethics, 20:4 (2011), pp. 515-23.

Beccalossi, C., 'Nineteenth-century European psychiatry on same-sex desires: pathology, abnormality, normality and the blurring of boundaries', Psychology \& Sexuality, 1:3 (2010), pp. 226-38.

Benninghaus, C., 'Beyond constructivism?: Gender, medicine and the early history of sperm analysis, Germany 1870-1900', Gender \& History, 24:3 (2012), pp. 647-76.

Bland, L. and L. Hall, 'Eugenics in Britain: the view from the metropole', in A. Bashford and P. Levine (eds), The Oxford Handbook of the History of Eugenics (Oxford: Oxford University Press, 2010), pp. 213-27.

Borge, J., 'The Psychosexual Counselling Tapes of Dr Joan Malleson: New Theories.' Unpublished MA thesis, Institute of Historical Research, School of Advanced Study, University of London, 2012.

Borowy, I., Coming to Terms with World Health: The League of Nations Health Organisation 1921-1946 (Frankfurt am Main: Peter Lang, 2009).

Brock, C., English Women Surgeons and their Patients (1860-1918) (Cambridge: Cambridge University Press, 2017).

Brooke, S., "A new world for women?" Abortion law reform in Britain during the 1930s', The American Historical Review, 106:2 (2001), pp. 431-59.

Brooke, S., Sexual Politics: Sexuality, Family Planning and the British Left from the 1880 s to the Present Day (Oxford: Oxford University Press, 2011).

Brookes, B., Abortion in England 1900-67 (Beckenham: Croom Helm, 1988).

Busfield, J., 'Restructuring mental health services in twentieth century Britain' in M. Gijswijt-Hofstra and R. Porter (eds), Cultures of Psychiatry, Clio Medica 49 (Amsterdam: Rodopi, 1998), pp. 9-28.

Cahen, F., Gouverner les moeurs: la lutte contre l'avortement en France, 1890-1950 (Paris: Institut National d'Etudes Démographiques, 2016).

Cahen, F. and C. Capuano, 'La poursuite de la répression anti-avortement après Vichy', Vingtième Siècle Revue d'Histoire, 111:3 (2011), pp. 119-31.

Cahen, F. and A. Minard, 'Les mobilisations pour "la vie" et contre les "fléaux sociaux" dans l'entre-deux-guerres: essai de cartographie sociale', Histoire et Mesure, 31:2 (2016), pp. 141-70.

Carey, J., 'The racial imperatives of sex: birth control and eugenics in Britain, the United States and Australia in the interwar years', Women's History Review, 21:5 (2012), pp. 733-52.

Carol, A., Histoire de l'eugénisme en France: Les médecins et la procréation, XIXeXXe Siècle (Paris: Le Seuil, 1998).

Carribon, C. and A. Duetto, 'Le Bulletin de l'Association française des femmes médecins (1929-40). Un discours médical spécifique aux femmes?', Le Temps des médias, 23:2 (2014), pp. 46-8. 
Chesler, E., Woman of Valor: Margaret Sanger and the Birth Control Movement in America (New York: Simon and Schuster, 2007).

Chettiar, T., 'The Psychiatric Family: Citizenship, Private Life, and Emotional Health in Welfare-State Britain, 1945-79'. PhD dissertation, University of Evanston, Illinois, 2013.

Chorev, N., The World Health Organization between North and South (Ithaca, NY: Cornell University Press, 2012).

Clarke, A., Disciplining Reproduction: Modernity, American Life Sciences, and 'the Problems of Sex' (Berkeley: University of California Press, 1998).

Clarke, S., 'Pure science with a practical aim: the meanings of fundamental research in Britain, circa 1916-1950', Isis, 101:2 (2010), pp. 285-311.

Cohen, D. A., 'Private lives in public spaces: Marie Stopes, the mothers' clinics and the practice of contraception', History Workshop Journal, 35:1 (1993), pp. 95-116.

Cole, J., The Power of Large Numbers: Population, Politics, and Gender in Nineteenth-Century France (Ithaca, NY: Cornell University Press, 2000).

Collins, M., Modern Love: An Intimate History of Men and Women in TwentiethCentury Britain (London: Atlantic Books, 2003).

Connelly, M., Fatal Misconception: The Struggle to Control World Population (Cambridge: The Belknap Press of Harvard University Press, 2009).

Conrad, P., 'Medicalization and social control', Annual Review of Sociology, 18:1 (1992), pp. 209-32.

Conrad, P., The Medicalization of Society: On the Transformation of Human Conditions into Treatable Disorders (Baltimore: Johns Hopkins University Press, 2007).

Cook, M., London and the Culture of Homosexuality (Cambridge: Cambridge University Press, 2003).

Cook, H., The Long Sexual Revolution: English Women, Sex, and Contraception 1800-1975 (Oxford: Oxford University Press, 2004).

Cook, H., 'Sex and the doctors: the medicalisation of sexuality as a two-way process in early to mid-twentieth-century Britain', in W. de Blécourt and C. Usborne (eds), Cultural Approaches to the History of Medicine (Basingstoke: Palgrave Macmillan, 2004), pp. 192-211.

Cook, H., 'The English sexual revolution: technology and social change', History Workshop Journal, 59:1 (2005), pp. 109-28.

Cova, A., Au service de l'Eglise, de la patrie et de la famille: femmes catholiques et maternité sous la III République (Paris: L'Harmattan, 2000).

Cox-Maksimov, D., 'The Making of the Clinical Trial in Britain, 1910-45: Expertise, the State and the Public'. PhD thesis, University of Cambridge, 1997.

Crowther, A. and M. Dupree, Medical Lives in the Age of Surgical Revolution (Cambridge: Cambridge University Press, 2010). 
Crozier, I., 'Social construction in a cold climate: a response to David Harley, "Rhetoric and the Social Construction of Sickness and Healing" and to Paolo Palladino's comment on Harley', Social History of Medicine, 13:3 (2000), pp. 535-46.

Crozier, I., 'Becoming a sexologist: Norman Haire, the 1929 London World League for Sexual Reform Congress, and organising medical knowledge about sex in interwar England', History of Science, 39:3 (2001), pp. 299-329.

Crozier, I., 'The medical construction of homosexuality and its relation to the law in nineteenth-century England', Medical History, 45:1 (2001), pp. 61-82.

Crozier, I., “All the world's a stage”: Dora Russell, Norman Haire, and the 1929 London World League for Sexual Reform Congress', Journal of the History of Sexuality, 12:1 (2003), pp. 16-37.

Cryle, P. and A. Moore, Frigidity: An Intellectual History (Basingstoke: Palgrave Macmillan, 2011).

Cunningham, A. and P. Williams, The Laboratory Revolution in Medicine (Cambridge: Cambridge University Press, 2002).

Dale, P. and K. Fisher, 'Contrasting municipal responses to the provision of birth control services in Halifax and Exeter before 1948', Social History of Medicine, 23:3 (2010), pp. 567-85

Daly, M., Gyn/Ecology: The Metaethics of Radical Feminism (Boston, MA: Beacon Press, 1978).

Davey, C., 'Birth control in Britain during the interwar years: evidence from the Stopes correspondence', Journal of Family History, 13:3 (1988), pp. 329-45.

Davidoff, L. et al., The Family Story: Blood, Contract and Intimacy (London: Longman, 1998).

Davin, A., 'Imperialism and motherhood', History Workshop Journal, 5:1 (1978), pp. 9-65.

Davis, G., 'Health and sexuality' in Mark Jackson (ed.), Oxford Handbook on the History of Medicine (Oxford: Oxford University Press, 2011), pp. 504-23.

Davis, G., 'A tragedy as old as history, medical response to infertility in Britain' in G. Davis and T. Loughran (eds), The Palgrave Handbook of Infertility in History: Approaches, Contexts and Perspectives (London: Palgrave Macmillan, 2017), pp. 359-81.

Davis, G. and T. Loughran (eds), The Palgrave Handbook of Infertility in History: Approaches, Contexts and Perspectives (London: Palgrave Macmillan, 2017).

De Luca Barrusse, V., Les familles nombreuses: une question démographique, un enjeu politique: France, 1880-1940 (Rennes: Presses Universitaires de Rennes, 2008).

De Luca Barrusse, V., 'Pro-natalism and hygienism in France, 1900-40. The example of the fight against venereal disease', Population, 64:3 (2009), pp. 477-506. 
De Luca Barrusse, V. and A.-F. Praz, 'Les Politiques de Population: Resituer Lobjet de Recherche', Annales de Démographie Historique, 1:129 (2016), pp. 149-64.

Debenham, C., Birth Control and the Rights of Women: Post-Suffrage Feminism in the Early Twentieth Century (London: I. B. Tauris, 2014).

deVries, J. R., 'A moralist and moderniser: Mary Scharlieb and the creation of gynecological knowledge, ca. 1880-1914', Social Politics, 22:3 (2015), pp. 298-318.

Digby, A., Making a Medical Living: Doctors and Patients in the English Market for Medicine, 1720-1911 (Cambridge: Cambridge University Press, 1994).

Digby, A., The Evolution of British General Practice 1850-1948 (Oxford: Oxford University Press, 1999).

Dose, R., 'The World League for Sexual Reform: some possible approaches', Journal of the History of Sexuality, 12:1 (2003), pp. 1-15.

Drouard, A., 'Aux origines de l'eugénisme en France: le néo-malthusianisme (1896-1914)', Population, 47:2 (1992), pp. 435-59.

Duden, B., The Woman Beneath the Skin: A Doctor's Patients in EighteenthCentury Germany (New Haven: Harvard University Press, 1991).

Dugdale, A., 'Devices and Desires: Constructing the Intrauterine Device, 1908-1988. PhD thesis, Department of Science and Technology Studies, University of Wollongong, 1995.

Dugdale, A., 'Inserting Gräfenberg's IUD into the sex reform movement', in D. MacKenzie and J. Wajcman (eds), The Social Shaping of Technology (Buckingham: Open University Press, 1999).

Dugdale, A., 'Intrauterine contraceptive devices, situated knowledges, and the making of women's bodies', Australian Feminist Studies, 15:32 (2000), pp. $165-76$.

Dyhouse, C., 'Driving ambitions: women in pursuit of a medical education, 1890-1939', Women's History Review, 7:3 (1998), pp. 321-43.

Dyhouse, C., 'Women students and the London medical schools, 1914-39: the anatomy of a masculine culture', Gender \& History, 10:1 (1998), pp. 110-32.

Ehrenreich, B. and D. English, Witches, Midwives and Nurses: A History of Women Healers (New York: The Feminist Press, 1973).

Elston, M. A. C., 'Women Doctors in the British Health Services: A Sociological Study of Their Careers and Opportunities.' PhD dissertation, University of Leeds, 1986.

Elston, M. A., "'Run by women, (mainly) for women”: medical women's hospitals in Britain, 1866-1948' in A. Hardy and L. Conrad (eds), Women and Modern Medicine, Clio Medica 61 (Leiden: Brill Rodopi, 2001), pp. 73-107.

Evans, B., Freedom to Choose: The Life and Work of Dr Helena Wright, Pioneer of Contraception (London: The Bodley Head, 1984). 
Featherstone, L., 'The science of pleasure: medicine and sex therapy in mid-twentieth-century Australia', Social History of Medicine, 31:3 (2018), pp. 445-61.

Fette, J., 'Pride and prejudice in the professions: women doctors and lawyers in Third Republic France', Journal of Women's History, 19:3 (2007), pp. 60-86.

Finch, J. and P. Summerfield, 'Social reconstruction and the emergence of companionate marriage, 1945-59', D. Clarke (ed.), Marriage, Domestic Life and Social Change: Writings for Jacqueline Burgoyne (1944-88) (London: Routledge, 1991), pp. 7-32.

Firestone, S., The Dialectic of Sex: The Case for Feminist Revolution (London: Jonathan Cape, 1971).

Fisher, K., 'Contrasting cultures of contraception: birth control clinics and the working-classes between the wars' in M. Gijswijt-Hofstra, G. M. van Heteren and T. Tansey (eds), Biographies of Remedies: Drugs, Medicines and Contraceptives in Dutch and Anglo-American Healing Cultures, Clio Medica 66 (Amsterdam: Rodopi, 2002), pp. 141-57.

Fisher, K., Birth Control, Sex and Marriage in Britain, 1918-60 (Oxford: Oxford University Press, 2006).

Fishman, J. R., 'Making viagra: from impotence to erectile dysfunction' in A. Tone and E. Siegel Watkins (eds), Medicating Modern America (New York: New York University Press, 2007), pp. 229-52.

Fishman, J. R., 'The biomedicalisation of female sexual dysfunction' in A. Clarke et al. (eds), Biomedicalisation: Theorising Technoscientific Transformation in the United States (Durham: Duke University Press, 2010), pp. 289-306.

Fishman, J. R., 'Manufacturing desire: the commodification of female sexual dysfunction', in S. Sismondo and J. Greene (eds), The Pharmaceutical Studies Reader (Hoboken: Wiley-Blackwell, 2015), pp. 106-20.

Foucault, M., La volonté de savoir: histoire de la sexualité 1 (Paris: Gallimard, 1976).

Franklin, S. and H. Ragoné (eds), Reproducing Reproduction: Kinship, Power, and Technological Innovation (Philadelphia: University of Pennsylvania Press, 1998).

Freeden, M., 'Eugenics and progressive thought: a study in ideological affinity', The Historical Journal, 22:3 (1979), pp. 645-71.

Freud, S., Three Essays on the Theory of Sexuality: The 1905 Edition (New York: Verso, 2017).

Gardey, D. and I. Hasdeu, 'Cet obscur sujet du désir', Travail, genre et sociétés, 2:34 (2015), pp. 73-92.

Gelly, M., Avortement et contraception dans les études médicales: une formation inadaptée (Paris: Editions l'Harmattan, 2006). 
Giami, A., 'De l'impuissance à la dysfonction érectile. Destins de la médicalisation de la sexualité, in D. Fassin and D. Memmi (eds), Le Gouvernement des Corps (Paris: Éditions de l'EHESS, 2004), pp. 77-108.

Gillis, R., L. A. Tilly and D. Levine (eds), The European Experience of Declining Fertility: A Quiet Revolution 1850-1970 (Cambridge: Blackwell, 1992).

Gordon, F., The Integral Feminist: Madeleine Pelletier, 1874-1939 (Minneapolis: University of Minnesota Press, 1991).

Gordon, L., The Moral Property of Women: A History of Birth Control Politics in America (Urbana: University of Illinois Press, 2002).

Gowing, L., Common Bodies: Women, Touch and Power in Seventeenth-Century England (New Haven: Yale University Press, 2003).

Grant, N., The Selling of Contraception: The Dalkon Shield Case, Sexuality, and Women's Autonomy (Columbus: Ohio State University Press, 1992).

Grier, J., 'Eugenics and birth control: contraceptive provision in North Wales, 1918-1939', Social History of Medicine, 11:3 (1998), pp. 443-8.

Grossman, A., Reforming Sex: The German Movement for Birth Control and Abortion Reform, 1920-50 (Oxford: Oxford University Press, 1995).

Gruber, H., 'French women in the crossfire of class, sex, maternity and citizenship', in H. Gruber and P. Graves (eds), Women and Socialism, Socialism and Women: Europe between the Two World Wars (New York: Berghahn Books, 1998), pp. 279-320.

Hall, L., "The English have hot-water bottles": The Morganatic marriage between sexology and medicine in Britain since William Acton', in R. Porter and M. Teich (eds), Sexual Knowledge, Sexual Science: The History of Attitudes to Sexuality (Cambridge: Cambridge University Press, 1994), pp. 350-66.

Hall, L. A., 'Marie Stopes and her correspondents: personalising population decline in an era of demographic change', in R. Peel (ed.), Marie Stopes, Eugenics and the English Birth Control Movement (London: Galton Institute, 1997), pp. 27-48.

Hall, L. A., 'Malthusian mutations: the changing politics and moral meanings of birth control in Britain' in B. Dolan, Malthus, Medicine and Morality, Clio Medica 59 (Leiden: Brill Rodopi, 2000), pp. 141-63.

Hall, L. A., 'A suitable job for a woman: women doctors and birth control to the inception of the NHS' in A. Hardy and L. Conrad (eds), Women and Modern Medicine, Clio Medica 61 (Leiden: Brill Rodopi, 2001), pp. 127-47.

Hall, L. A., 'In ignorance and in knowledge: reflections on the history of sex education in Britain', in L. D. H. Sauerteig and R. Davidson (eds), Shaping Sexual Knowledge: A Cultural History of Sex Education in Twentieth Century Europe (London: Routledge, 2009), pp. 19-36.

Hall, L.A., The Life and Times of Stella Browne: Feminist and Free Spirit (London: I. B. Tauris, 2011). 
Hall, L., Sex, Gender and Social Change in Britain since 1880, 2nd edition (Basingstoke: Palgrave Macmillan, 2012).

Hall, L. A., Outspoken Women: An Anthology of Women's Writing on Sex, 1870-1969. (London: Routledge, 2014).

Hanley, A. R., Medicine, Knowledge and Venereal Diseases in England, 1886-1916 (London: Palgrave Macmillan, 2017).

Herzog, D., Sexuality in Europe: A Twentieth-Century History (Cambridge: Cambridge University Press, 2011).

Hilevych, Y., 'Abortion and gender relationships in Ukraine, 1955-1970', The History of the Family, 20:1 (2015), pp. 86-105.

Hodder, J., S. Legg and M. Heffernan, 'Introduction: historical geographies of internationalism, 1900-1950', Political Geography, 49 (2015), pp. 1-6.

Hodges, S., Contraception, Colonialism and Commerce: Birth Control in South India, 1920-1940 (Aldershot: Ashgate, 2008).

Hodgson, D. and S. Watkins, 'Feminists and neo-Malthusians: past and present alliances', Population and Development Review, 23:3 (1997), pp. 469-523.

Hoggart, L., 'The campaign for birth control in Britain in the 1920s' in A. Digby and J. Stewart (eds), Gender, Health and Welfare (London: Routledge, 1996), pp. 143-66.

Hoggart, L., 'Socialist feminism, reproductive rights and political action', Capital and Class, 24:1 (2012), pp. 95-125.

Houlbrook, M., Queer London: Perils and Pleasures in the Sexual Metropolis, 1918-57 (Chicago: University of Chicago Press, 2005).

Hull, A., 'Teamwork, clinical research, and the development of scientific medicines in interwar Britain: the 'Glasgow School' revisited', Bulletin of the History of Medicine, 81:3 (2007), pp. 569-93.

Huss, M.-M., 'Pronatalism in the inter-war period in France', Journal of Contemporary History, 25:1 (1990), pp. 39-68.

Ignaciuk, A., 'No Man's Land? Gendering contraception in family planning advice literature in state-Socialist Poland (1950s-80s)', Social History of Medicine, hkz007, available at: https://doi.org/10.1093/shm/hkz007 (accessed 25 June 2020).

Irvine, J., 'From difference to sameness: gender ideology in sexual science', The Journal of Sex Research, 27:1(1990), pp. 7-24.

Irwin, R., "'To try and find out what is being done to whom, by whom and with what results": the creation of psychosexual counselling policy in England, 1972-79', Twentieth Century British History, 20:2 (2009), pp. 173-97.

Irwin, R., 'Recalling the early years of psychosexual nursing', Oral History, 39:1 (2011), pp. 43-52.

Jackson, M., The Real Facts of Life: Feminism and the Politics of Sexuality, c.1850-1940 (London: Taylor \& Francis, 1994). 
Janz, O. and D. Schönpflug (eds), Gender and History in a Transnational Perspective: Biographies, Networks, Gender Orders (Oxford: Berghahn, 2014).

Jones, C. L., 'Under the covers? Commerce, contraceptives and consumers in England and Wales, 1880-1960', Social History of Medicine, 29:4 (2016), pp. 734-56.

Jones, E. L., 'The establishment of voluntary family planning clinics in Liverpool and Bradford, 1926-60: A comparative study', Social History of Medicine, 24:2 (2011), pp. 352-69.

Jones, G., Social Hygiene in Twentieth Century Britain (London: Croom Helm, 1986).

Jones, G., 'Marie Stopes in Ireland. The mother's clinic in Belfast, 1936-47', Social History of Medicine, 5:2 (1992), pp. 255-77.

Jones, G., 'Women and eugenics in Britain: the case of Mary Scharlieb, Elizabeth Sloan Chesser, and Stella Browne', Annals of Science, 52:5 (1995), pp. 481-502.

Kelly, L., "Fascinating scalpel-wielders and fair dissectors": women's experience of Irish medical education c.1880s-1920s', Medical History, 54:4 (2010), p. 506.

Kelly, L., Irish Women in Medicine, c.1880s-1920s (Manchester: Manchester University Press, 2013).

Képès, S., Du corps à l'âme, entretiens avec Danielle M. Lévy (Paris: L'Harmattan, 1996).

Kevles, D. J., In the Name of Eugenics: Genetics and the Uses of Human Heredity (Berkeley: University of California Press, 1986).

King, H., The Disease of Virgins: Green Sickness, Chlorosis and the Problems of Puberty (London: Routledge, 2004).

Klausen, S. and A. Bashford, 'Fertility control: eugenics, neo-Malthusianism, and feminism' in A. Bashford and P. Levine (eds), The Oxford Handbook of the History of Eugenics (Oxford: Oxford University Press, 2010), pp. 98-115.

Kline, W., Bodies of Knowledge: Sexuality, Reproduction, and Women's Health in the Second Wave (Chicago: University of Chicago Press, 2010).

Kling, S., 'Reproductive health, birth control and fertility change in Sweden, circa 1900-40', The History of the Family, 15:2 (2010), pp. 161-73.

Knibiehler, Y., 'Léducation sexuelle des filles au XXe siècle', Clio: Femmes, Genre, Histoire, 4 (1996), pp. 419-82.

Knibiehler, Y., Accoucher: Femmes, sages-femmes et médecins depuis le milieu du 20e siècle (Rennes: Editions de l'Ecole des Hautes Etudes en Santé Publique, 2007).

Koos, C. A., 'Gender, anti-individualism, and nationalism: the Alliance Nationale and the pronatalist backlash against the femme moderne, 1933-40', French Historical Studies, 19:3 (1996), pp. 699-723. 
Kościańska, A., 'Sex on equal terms? Polish sexology on women's emancipation and "good sex" from the 1970s to the present', Sexualities, 19:1-2 (2016), pp. 236-56.

Langhamer, C., The English in Love: The Intimate Story of an Emotional Revolution (Oxford: Oxford University Press, 2013).

Laqueur, T., Making Sex: Body and Gender from the Greeks to Freud (Cambridge, MA: Harvard University Press, 1990).

Latham, M., Regulating Reproduction: A Century of Conflict in Britain and France (Manchester: Manchester University Press, 2002).

Lawrence, C., 'Still incommunicable: clinical holists and medical knowledge in interwar Britain' in C. Lawrence and G. Weisz (eds), Greater than the Parts: Holism in Biomedicine 1920-50 (Oxford: Oxford University Press, 1998), pp. 94-111.

Lawrence, C., 'A tale of two sciences: bedside and bench in twentieth-century Britain', Medical History, 43:4 (1999), pp. 421-49.

Leathard, A., The Fight for Family Planning: The Development of Family Planning Services in Britain, 1921-1974 (London: Macmillan Press, 1980).

Ledbetter, R., A History of the Malthusian League, 1877-1927 (Columbia: Ohio State University Press, 1986).

Lewis, J., The Politics of Motherhood: Child and Maternal Welfare in England, 1900-1939 (London: Croom Helm, 1980).

Lewis, J., 'The working-class wife and mother and state intervention, 1870-1918' in J. Lewis (ed.), Women's Experience of Home and Family, 1850-1940 (Oxford: Blackwell, 1986).

Lewis, J., D. Clark and D. Morgan, Whom God Hath Joined Together: Work of Marriage Guidance (London: Routledge, 1992).

Linder, D. H., 'Crusader for Sex Education': Elise Ottesen-Jensen (1886-1973) in Scandinavia and on the International Scene (Lanham, MD: University Press of America, 1996).

Lišková, K., Sexual Liberation, Socialist Style: Communist Czechoslovakia and the Science of Desire, 1945-89 (Cambridge: Cambridge University Press, 2018).

Loe, M., The rise of Viagra: How the Little Blue Pill changed Sex in America (New York: New York University Press, 2004).

Loeb, L., 'Doctors and patent medicines in modern Britain: professionalism and consumerism', Albion, 33:3 (2001), pp. 404-25.

Löwy, I., "Sexual chemistry" before the pill: science, industry and chemical contraceptives, 1920-1960', British Journal for the History of Science, 44:2 (2011), pp. 245-74.

Löwy, I. and G. Weisz, 'French hormones: progestins and therapeutic variation in France', Social Science \& Medicine, 60:11 (2005), pp. 2609-22. 
Mackenzie, D., Statistics in Britain, 1865-1930: The Social Construction of Scientific Knowledge (Edinburgh: Edinburgh University Press, 1981).

Macnicol, J., 'Eugenics and the campaign for voluntary sterilization in Britain between the wars', Social History of Medicine, 2:2 (1989), pp. 147-69.

Makepeace, C., 'To what extent was the relationship between feminists and the eugenics movement a "marriage of convenience" in the interwar years?', Journal of International Women's Studies, 11:3 (2009), pp. 66-80.

Malleson, A., Discovering the Family of Miles Malleson 1888-1969 (2012) [online], available at: https://books.google.co.uk/books?id=WBVhkj_ JAJ8C \&printse $=$ frontcover \&dq $=$ discovering + the + family + of + miles + malleson\&hl=en\&sa=X\&ved=0ahUKEwib0bDQ6MPlAhX4RBUIHebw B 1gQuwUILTAA\# $v=$ onepage \&q=discovering\%20the $\% 20$ family $\% 20$ of\%20miles\%20malleson\&f=false (accessed 30 October 2019).

Marks, L., Metropolitan Maternity: Maternal and Infant Welfare Services in Early Twentieth Century London (Amsterdam: Rodopi, 1996).

Marks, L., Sexual Chemistry: A History of the Contraceptive Pill (New Haven: Yale University Press, 2001).

Marland, H., 'Women, health and medicine' in M. Jackson (ed.), The Oxford Handbook on the History of Medicine (Oxford: Oxford University Press, 2011), pp. 484-502.

Maynes, M. J., B. Søland and C. Benninghaus, Secret Gardens, Satanic Mills: Placing Girls in European History, 1750-1960 (Bloomington: Indiana University Press, 2005).

Mazumdar, P., Eugenics, Human Genetics and Human Failings: The Eugenics Society, Its Sources and Its Critics in Britain (London: Routledge, 2005).

McCarthy, H., Women of the World: The Rise of the Female Diplomat (London: Bloomsbury, 2014).

McClive, C., 'The hidden truths of the belly: the uncertainties of pregnancy in early modern Europe', Social History of Medicine, 15:2 (2002), pp. 209-27.

McLaren, A., Birth Control in Nineteenth-Century England (London: Croom Helm, 1978).

McLaren, A., Twentieth-Century Sexuality: A History (Oxford: Oxford University Press, 1999).

McLaren, A., Reproduction by Design: Sex, Robots, Trees, and Test-Tube Babies in Interwar Britain (Chicago: University of Chicago Press, 2012).

Michaelsen, K., 'Union is strength: the Medical Women's Federation and the politics of professionalism, 1917-30' in K. Cowman and L. Jackson (eds), Women and Work Culture, Britain c.1850-1950 (Aldershot: Ashgate, 2005), p. 165.

Mitchell, C., 'Madeleine Pelletier (1874-1939): the politics of sexual oppression', Feminist Review, 33 (1989), pp. 72-92. 
Mold, A., 'Repositioning the patient: patient organisations, consumerism, and autonomy in Britain during the 1960s and 1970s', Bulletin of the History of Medicine, 87:2 (2013), pp. 225-49.

Moore, A., 'Relocating Marie Bonaparte's clitoris', Australian Feminist Studies, 24:60 (2009), pp. 149-65.

Morantz-Sanchez, R., Sympathy and Science: Women Physicians in American Medicine (Oxford: Oxford University Press, 1985).

More, E. S., E. Fee and M. Parry (eds), Women Physicians and the Cultures of Medicine (Baltimore: Johns Hopkins University Press, 2009).

Moscucci, O., The Science of Woman: Gynaecology and Gender in England, 1800-1929 (Cambridge: Cambridge University Press, 1990).

Moulin, A. M., 'The Pasteur Institute's international network: scientific innovations and French tropisms' in C. Charle, J. Schriewer and P. Wagner (eds), Transnational Intellectual Networks: Forms of Academic Knowledge and the Search for Cultural Identities (Frankfurt: Campus Verlag, 2004), pp. 135-62.

Moynihan, R., 'The making of a disease: female sexual dysfunction', British Medical Journal, 326:7379 (2003), pp. 45-7.

Murphy, M., Seizing the Means of Reproduction: Entanglements of Feminism, Health, and Technoscience (Durham, NC: Duke University Press, 2012).

Neill, D., Networks in Tropical Medicine: Internationalism, Colonialism, and the Rise of a Medical Specialty, 1890-1930 (Stanford: Stanford University Press, 2012).

Neuhaus, J., 'The importance of being orgasmic: sexuality, gender, and marital sex manuals in the United States, 1920-63', Journal of the History of Sexuality, 9:4 (2000), pp. 447-73.

Oakley, A., The Captured Womb: A History of the Medical Care of Pregnant Women (Oxford: Basil Blackwell Publisher Ltd., 1984).

Offen, K., 'Depopulation, nationalism, and feminism in fin-de-siècle France', The American Historical Review, 89:3 (1984), pp. 648-76.

Offen, K., Les féminismes en Europe (1700-1950): une histoire politique (Rennes: Presses Universitaires de Rennes, 2012).

Ogden, P. E. and M.-M. Huss, 'Demography and pronatalism in France in the nineteenth and twentieth centuries', Journal of Historical Geography, 8:3 (1982), pp. 283-98.

Olszynko-Gryn, J., 'The demand for pregnancy testing: the Aschheim-Zondek reaction, diagnostic versatility, and laboratory services in 1930s Britain', Studies in History and Philosophy of Science Part C: Studies in History and Philosophy of Biological and Biomedical Sciences, 47 (2014), pp. 233-47.

Olszynko-Gryn, J., 'Technologies of contraception and abortion' in N. Hopwood, R. Flemming and L. Kassell (eds), Reproduction: Antiquity to the Present (Cambridge: Cambridge University Press, 2018), pp. 535-51. 
Olszynko-Gryn, J., 'The feminist appropriation of pregnancy testing in 1970s Britain', Women's History Review, 28:6 (2019), pp. 869-94.

Olszynko-Gryn, J. and C. Rusterholz (eds), 'Introduction: Reproductive Politics in Britain and France', Medical History, 63:2 (2019), pp. 117-33.

Ortiz-Gómez, T. and A. Ignaciuk, 'The fight for family planning in Spain during late Francoism and the transition to democracy, 1965-79', Journal of Women's History, 30:2 (2018), pp. 38-62.

Oudshoorn, N., Beyond the Natural Body: An Archaeology of Sex Hormones (London: Routledge, 1994).

Parry, M., Broadcasting Birth Control: Mass Media and Family Planning (New Brunswick: Rutgers University Press, 2013).

Pavard, B., 'Du birth control au planning familial (1955-60): un transfert militant', Histoire@Politique, 18:3 (2012),pp. 162-78.

Pavard, B., 'Si je veux, quand je veux': Contraception et avortement dans la société française (1956-79) (Rennes: Presses Universitaires de Rennes, 2012).

Pedersen, J. E., 'Regulating abortion and birth control: gender, medicine, and republican politics in France, 1870-1920', French Historical Studies, 19:3 (1996), pp. 673-98.

Pedersen, S., Family, Dependence, and the Origins of the Welfare State: Britain and France, 1914-1945 (Cambridge: Cambridge University Press, 1995).

Peel, J., 'Contraception and the medical profession', Population Studies, 18:2 (1964), pp. 133-45.

Pfeffer, N., The Stork and the Syringe: A Political History of Reproductive Medicine (Cambridge: Polity Press, 1993).

Philippe, B., 'Suzanne Képès, une femme d'exception', Le Carnet PSY, 6:101 (2005), p. 36.

Pinell, P., 'Champ médical et processus de spécialisation', Actes de la Recherche en Sciences Sociales, 1 (2005), pp. 4-36.

Porter, R. and L. Hall, The Facts of Life: The Creation of Sexual Knowledge in Britain, 1650-1950 (New Haven: Yale University Press, 1995).

Pringle, R., Sex and Medicine: Gender, Power and Authority in the Medical Profession (Cambridge: Cambridge University Press, 1998).

Ramsden, E., 'Social demography and eugenics in the interwar United States', Population and Development Review, 29:4 (2003), pp. 547-93.

Ratcliff, K., Women and Health: Power, Technology, Inequality and Conflict in a Gendered World (Boston, MA: Allyn and Bacon, 2002)

Rebreyend, A.-C., Intimités amoureuses: France 1920-75 (Toulouse: Presses Universitaires du Mirail, 2008).

Reggiani, A. H., 'Procreating France: the politics of demography, 1919-45', French Historical Studies, 19:3 (1996), pp. 725-54. 
Reinish, J. (ed.), 'Agents of internationalism', Contemporary European History, 25:2 (2016), pp. 195-205.

Roemer, M., 'Internationalism in medicine and public health' in D. Porter (ed.), The History of Public Health and the Modern State (Amsterdam: Rodopi, 1994), pp. 403-22.

Ronsin, F., La grève des ventres: propagande néo-malthusienne et baisse de la natalité française, XIXe-XXe siècles (Paris: Aubier Montaigne, 1980).

Rose, J., Marie Stopes and the Sexual Revolution (London: Faber and Faber, 1992).

Rose, N., 'Beyond medicalization', Lancet, 369:9562 (2007), pp. 700-2.

Rosental, P.-A., L'Intelligence démographique: Sciences et politiques des populations en France (1930-1960) (Paris: Odile Jacob, 2003).

Rusterholz, C., 'Testing the Gräfenberg ring in interwar Britain: Norman Haire, Helena Wright, and the debate over statistical evidence, side effects, and intra-uterine contraception', Journal of the History of Medicine and Allied Sciences, 72:4 (2017), pp. 448-67.

Rusterholz, C., 'English and French women doctors in international debates on contraception (1920-1935)', Social History of Medicine, 31:2 (2018), pp. 328-47.

Rusterholz, C., 'English women doctors, contraception and family planning in transnational perspective (1930s-70s)', Medical History, 63:2 (2019), pp. 153-72.

Rusterholz, C., "'You can't dismiss that as being less happy, you see it is different". Sexual therapy in 1950s England', Twentieth Century British History, 30:3 (2019), pp. 375-98.

Sauerteig, L. D. H. and R. Davidson (eds), Shaping Sexual Knowledge: A Cultural History of Sex Education in Twentieth Century Europe (London: Routledge, 2009).

Schneider, W. H., Quality and Quantity: The Quest for Biological Regeneration in Twentieth-Century France (Cambridge: Cambridge University Press, 2002).

Shortt, S. E. D., 'Physicians, science, and status: issues in the professionalisation of Anglo-American medicine in the nineteenth century', Medical History, 27:1 (1983), pp. 51-68.

Simmons, C., Making Marriage Modern: Women's Sexuality from the Progressive Era to World War II (Oxford: Oxford University Press, 2009).

Sohn, A.-M., Du premier baiser à l'alcôve: La sexualité des Français au quotidien (1850-1950) (Paris: Aubier, 1996).

Soloway, R. A., 'Neo-Malthusians, eugenists, and the declining birth-rate in England, 1900-1918' Albion, 10:3 (1978), pp. 264-86.

Soloway, R. A., Birth Control and the Population Question in Britain, 1870-1930 (Chapel Hill: University of North Carolina Press, 1982). 
Soloway, R. A., Demography and Degeneration: Eugenics and the Declining Birthrate in Twentieth-Century Britain (Chapel Hill: University of North Carolina Press, 1990).

Soloway, R. A., 'The "perfect contraceptive": eugenics and birth control research in Britain and America in the interwar years', Journal of Contemporary History, 30:4 (1995), pp. 637-64.

Soloway, R., 'The Galton Lecture 1996: Marie Stopes, eugenics, and the birth control movement' in R. Peel (ed.), Marie Stopes: Eugenics and the English Birth Control Movement (London: Galton Institute, 1997), pp. 49-76.

Sonn, R. D., "'Your body is yours": anarchism, birth control, and eugenics in interwar France', Journal of the History of Sexuality, 14:4 (2005), pp. 415-32.

Strange, J.-M., 'The assault on ignorance: teaching menstrual etiquette in England, c.1920s to 1960s', Social History of Medicine, 14:2 (2001), pp. 247-65.

Sturdy, S., 'The political economy of scientific medicine: science, education and the transformation of medical practice in Sheffield, 1890-1922', Medical History, 36:2 (1992), pp. 125-59.

Sturdy, S., 'Looking for trouble: medical science and clinical practice in the historiography of modern medicine', Social History of Medicine, 24:3 (2011), pp. 739-57.

Sturdy, S. and R. Cooter, 'Science, scientific management, and the transformation of medicine in Britain c.1870-1950', History of Science, 36:114 (1998), pp. 421-66.

Sutton, C., 'Hysterectomy: a historical perspective', Baillière's Clinical Obstetrics and Gynaecology, 11:1 (1997), pp. 1-22.

Sylvest, C., 'Continuity and change in British liberal internationalism, c.1900-1930', Review of International Studies, 31:2 (2005), pp. 263-83.

Szreter, S., 'The idea of demographic transition and the study of fertility change: a critical intellectual history', Population and Development Review, 19:4 (1993), pp. 659-701.

Szreter, S., Fertility, Class and Gender in Britain, 1860-1940 (Cambridge: Cambridge University Press, 2002).

Szreter, S., Health and Wealth: Studies in History and Policy (Rochester, NY: University of Rochester Press, 2005).

Szreter, S. and K. Fisher, Sex Before the Sexual Revolution (Cambridge: Cambridge University Press, 2010).

Szuhan, N., 'Sex in the laboratory: the Family Planning Association and contraceptive science in Britain, 1929-1959', The British Journal for the History of Science, 51:3 (2018), pp. 1-24.

Takeshita, C., The Global Biopolitics of the IUD: How Science Constructs Contraceptive Users and Women's Bodies (Cambridge, MA: MIT Press, 2012). 
Tamagne, F., La Ligue Mondiale Pour La Réforme Sexuelle: La science au service de l'émancipation sexuelle? (Paris: Editions Belin, 2005).

Tammeveski, P., 'Repression and incitement: a critical demographic, feminist, and transnational analysis of birth control in Estonia, 1920-39', The History of the Family, 16:1 (2011), pp. 13-29.

Teitelbaum, M. S., The British Fertility Decline: Demographic Transition in the Crucible of the Industrial Revolution (Princeton: Princeton University Press, 2014).

Thane, P., 'Visions of gender in the making of the British welfare state: the case of women in the British Labour Party and social policy, 1906-45' in G. Bock and P. Thane (eds), Maternity and Gender Policies: Women and the Rise of the European Welfare States 1880s-1950s (London: Routledge, 1991), pp. 93-118.

Thomsen, R. J., 'Historical: Ernst Gräfenberg and the golden year of the silver ring' in E. S. Hafez and W. A. van Os (eds), Medicated Intrauterine Devices: Physiological and Clinical Aspects (The Hague: Springer Netherlands, 1980), pp. 3-8.

Timmerman, C., 'Clinical research in postwar Britain, the role of the Medical Research Council' in C. Hannaway (ed.), Biomedicine in the 20th Century: Practices, Policies and Politics (Amsterdam: IOS Press, 2008), pp. 231-54.

Toms, J., Mental Hygiene and Psychiatry in Modern Britain (Basingstoke: Palgrave Macmillan, 2013).

Toms, J., 'MIND, Anti-Psychiatry, and the Case of the Mental Hygiene Movement's "Discursive Transformation", Social History of Medicine, online, hky096, available at: https://doi.org/10.1093/shm/hky096 (accessed 25 June 2020).

Tone, A., Devices and Desires: A History of Contraceptives in America (New York: Farrar, Straus and Giroux, 2001).

Tong, R., Feminist Approaches to Bioethics: Theoretical Reflections and Practical Applications (Boulder: Westview Press, 1997).

Toth, B., 'Clinical Trials in British Medicine 1858-1948, with Special Reference to the Development of the Randomised Controlled Trial'. PhD thesis, University of Bristol, 1998.

Usborne, C., 'Women doctors and gender identity in Weimar Germany (1918-1933)' in A. Hardy and L. Conrad (eds), Women and Modern Medicine, Clio Medica 61 (Leiden: Brill Rodopi, 2001), pp. 109-26.

Vuille, M., 'Le désir sexuel des femmes, du DSM à la nouvelle médecine sexuelle', Genre, sexualité \& société, online, 2014, available at: http:// gss.revues.org/3240 (accessed 25 June 2020).

Walker, C. E. L., 'Making Birth Control Respectable: The Society for Constructive Birth Control and Racial Progress, and the American Birth Control 
League, in Comparative Perspective, 1921-38. PhD dissertation, University of Bristol, 2007.

Wandor, M. (ed.), The Body Politic: Writings from the Women's Liberation Movement in Britain 1969-1972 (London: Stage, 1972).

Weatherall, M. W., 'Making medicine scientific: empiricism, rationality, and quackery in mid-Victorian Britain', Social History of Medicine, 9:2 (1996), pp. 175-94.

Weindling, P. (ed.), International Health Organisations and Movements, 1918-39 (Cambridge: Cambridge University Press, 1995).

Welshman, J., 'In Search of the "Problem Family": Public Health and Social Work in England and Wales 1940-70', Social History of Medicine, 9:3 (1996), pp. 447-65.

Welshman, J., 'Eugenics and public health in Britain, 1900-40: scenes from provincial life', Urban History, 24:1 (1997), pp. 56-75.

Welshman, J., Municipal Medicine: Public Health in Twentieth-Century Britain (Oxford: Peter Lang, 2000).

Whitfield, N. and T. Schlich (eds), 'Skills through history', Medical History, 59:3 (2015), pp. 349-85.

Wyndham, D., Norman Haire and the Study of Sex (Sydney: Sydney University Press, 2012). 